\title{
Physiological quality of seeds and growth of seedlings of chickpea under salt stress
}

\author{
Qualidade fisiológica de sementes e crescimento de plântulas de grão-de-bico sob estresse salino \\ Calidad fisiológica de semillas y crecimiento de plántulas de garbanzo bajo estrés salino
}

Received: 08/27/2021 | Reviewed: 09/05/2021 | Accept: 09/09/2021 | Published: 09/11/2021

\author{
Amanda Maria Leal Pimenta \\ ORCID: https://orcid.org/0000-0001-5827-8193 \\ State University of Montes Claros, Brazil \\ E-mail: amandaleal90@hotmail.com \\ Nelson de Abreu Delvaux Júnior \\ ORCID: https://orcid.org/0000-0003-4125-3744 \\ State University of Montes Claros, Brazil \\ E-mail: nelson.junior@unimontes.br \\ Sérgio Manoel da Silva Fernandes \\ ORCID: https://orcid.org/0000-0002-8483-1690 \\ State University of Montes Claros, Brazil \\ E-mail: sergiozoo15705@gmail.com \\ Josiane Cantuária Figueiredo \\ ORCID: https://orcid.org/0000-0001-7105-1241 \\ Federal University of Pelotas, Brasil \\ E-mail: josycantuaria@yahoo.com.br \\ Samy Pimenta \\ ORCID: https://orcid.org/0000-0002-9411-9381 \\ State University of Montes Claros, Brazil \\ E-mail: samy.pimenta@unimontes.br \\ Maria Josiane Martins \\ ORCID: https://orcid.org/0000-0003-1911-5679 \\ State University of Montes Claros, Brazil \\ E-mail: josianemartins102012@ @otmail.com \\ Danúbia Aparecida Costa Nobre \\ ORCID: https://orcid.org/0000-0002-5034-4480 \\ Federal University of Jequitinhonha and Mucuri Valleys, Brazil \\ E-mail: danubia.nobre@ufvjm.edu.br
}

\begin{abstract}
Salt stress is a condition that causes physiological changes in several species, the identifying cultivars tolerant to such conditions is essential to high salinity environments. The objective was to evaluate the physiological quality of seeds of chickpea cultivars to salt stress during germination and seedling growth. Two cultivars ('BRS Cícero' and 'BRS Aleppo') and five osmotic potentials simulated with sodium chloride solutions $(0.0 ;-0.2 ;-0.4 ;-0.6$ and $-0.8 \mathrm{MPa})$, were evaluated by the test of germination speed index, mean germination time, epicotyl and primary root length, epicotyl and primary root fresh mass, epicotyl and the primary root dry mass of the seeds were evaluated. Significant interactions were found for all variables, indicating that there are cultivars with specific performance for a particular salt condition, and the simulated salt stress conditions negatively affected germination and seedling growth. Osmotic potentials of less than -0.4 MPa are harmful to the germination and growth of chickpea seedlings. The 'BRS Cícero' seeds showed a higher salt tolerance than 'BRS Aleppo'. The cultivar BRS Aleppo has a longer epicotyl length compared to 'BRS Cícero' when subjected to the same conditions of salt stress.
\end{abstract}

Keywords: Cicer arietinum L.; Germination; Salinity tolerance; Sodium chloride.

\section{Resumo}

O estresse salino é uma condição que causa alterações fisiológicas em várias espécies, a identificação de cultivares tolerantes a tais condições é fundamental para ambientes de alta salinidade. O objetivo foi avaliar a qualidade fisiológica de sementes de cultivares de grão-de-bico ao estresse salino durante a germinação e crescimento de plântulas. Duas cultivares ('BRS Cícero' e 'BRS Aleppo') e cinco potenciais osmóticos simulados com soluções de cloreto de sódio $(0,0 ;-0,2 ;-0,4 ;-0,6$ e $-0,8 \mathrm{MPa})$, foram avaliados pelo teste de índice de velocidade de germinação, tempo médio de germinação, comprimento do epicótilo e da raiz primária, epicótilo e massa fresca da raiz primária, epicótilo e massa seca da raiz primária das sementes. Foram encontradas interações significativas para todas as variáveis, indicando que existem cultivares com desempenho específico para uma determinada condição de sal, e as condições simuladas de estresse salino afetaram negativamente a germinação e o crescimento das mudas. Potenciais osmóticos de menos de -0,4 MPa são prejudiciais à germinação e ao crescimento de mudas de grão-de-bico. As 
sementes 'BRS Cícero' apresentaram maior tolerância ao sal do que 'BRS Aleppo'. A cultivar BRS Aleppo apresenta maior comprimento do epicótilo em relação à 'BRS Cícero' quando submetida às mesmas condições de estresse salino.

Palavras-chave: Cicer arietinum L.; Germinação; Tolerância à salinidade; Cloreto de sódio.

\section{Resumen}

El estrés salino es una condición que ocasiona cambios fisiológicos en varias especies, la identificación de cultivares tolerantes a tales condiciones es fundamental para ambientes de alta salinidad. El objetivo fue evaluar la calidad fisiológica de semillas de cultivares de garbanzo al estrés salino durante la germinación y crecimiento de la plántula. Dos cultivares ('BRS Cícero' y 'BRS Aleppo') y cinco potenciales osmóticos simulados con soluciones de cloruro de sodio $(0.0 ;-0.2 ;-0.4 ;-0.6$ y $-0.8 \mathrm{MPa})$, fueron evaluados mediante la prueba de índice de velocidad de germinación, media Se evaluó el tiempo de germinación, epicotilo y longitud de raíz primaria, epicotilo y masa fresca de raíz primaria, epicotilo y masa seca de raíz primaria de las semillas. Se encontraron interacciones significativas para todas las variables, lo que indica que hay cultivares con desempeño específico para una condición de sal particular, y las condiciones de estrés salino simuladas afectaron negativamente la germinación y el crecimiento de las plántulas. Los potenciales osmóticos de menos de -0,4 MPa son perjudiciales para la germinación y el crecimiento de las plántulas de garbanzo. Las semillas 'BRS Cicero' mostraron una mayor tolerancia a la sal que 'BRS Aleppo'. El cultivar BRS Aleppo tiene una longitud de epicotilo más larga en comparación con 'BRS Cicero' cuando se somete a las mismas condiciones de estrés salino.

Palabras clave: Cicer arietinum L.; Germinación; Tolerancia a la salinidad; Cloruro de sodio.

\section{Introduction}

Chickpea (Cicer arietinum L.) is an important source of protein produced in many arid and semi-arid regions (Chauhan et al., 2017), occupying fifth place in the international production of legumes (Merga \& Raji, 2019).

The cultivation of chickpeas in northern Minas Gerais state (Brazil) is recommended to be carried out in the dry season in winter due to the advantage of the end of the rains or using supplementary irrigation (Avelar et al., 2018). Such irrigation comes mostly from artesian wells whose water is considered saline. The use of saline water is a limiting factor for agricultural production, in arid and semi-arid regions (Dias et al., 2016) due to the conditions of low rainfall and high balance of solar energy.

Salts affect plant growth due to raise in the soil osmotic pressure and to the interference with plant nutrition (Machado \& Serralheiro, 2017). The high concentration of salt in the soil solution reduces the ability of the plant in absorbing water (Acosta-Motos et al., 2017). Thus, according to Kumar et al. (2018), chickpeas are highly affected by salt stress.

The effect of salt stress on seed germination and seedling establishment has been studied in many species (Laghmouchi et al., 2017; Pereira et al., 2020). Salt stress inhibits or delays both seedling germination and growth due to osmotic effects (Iqbal et al., 2020). The first physiological disturbance caused by salt stress is the restriction of water uptake due to the reduction in the osmotic potential of the substrate, delaying the imbibition by the seeds or root elongation (Pereira et al., 2020). During seedling establishment, water uptake causes the accumulation of ions, which can affect cell division and differentiation (Ferreira et al., 2017) delaying the emergence of seedlings (Nascimento et al., 2017) and more drastically, reducing seed viability.

One alternative to overcome such issue in the semi-arid regions is the use of salt-tolerant chickpea cultivars. The tolerance to salinity of any crop is defined as the ability to withstand the effects of excess of salt in the root zone (Deepa \& Arumugam, 2019; Alqahtani et al., 2018). Salinity tolerance can vary among species and among cultivars of the same species (Sa et al., 2020). Therefore, the objective of this study was to evaluate the physiological quality of seeds of chickpea cultivars to salt stress during germination and seedling growth.

\section{Methodology}

The experiment was carried out at the Biotechnology Laboratory of the State University of Montes Claros, with chickpea seeds from the 2019 harvest produced by Embrapa Hortaliças, in Brasília, Federal District. 
It was used a completely randomized experimental design in a 2 x 5 factorial scheme, with four replications. The treatments consisted of two chickpea cultivars, BRS Cícero and BRS Aleppo and five levels of osmotic potentials (0; -0.2; 0.4; -0.6 and -0.8 MPa). The zero potential represented the control, without stress, for which distilled water was used.

To simulate salt stress, sodium chloride $(\mathrm{NaCl})$ solutions were prepared following the Van`t Hoff equation (Salisbury \& Ross, 1992), in which: $\Psi$ os = osmotic potential $(\mathrm{MPa}) ; \mathrm{C}=$ concentration $\left(\mathrm{mol} \mathrm{L}^{-1}\right)$; $\mathrm{i}=$ isotonic coefficient; $\mathrm{R}=$ general gas constant $\left(0.0082 \mathrm{MPa} \mathrm{mol}^{-1} \mathrm{~K}^{-1}\right)$ and $\mathrm{T}=$ temperature $(\mathrm{K})$.

For the germination test, four replications of 50 seeds per treatment were used. The seeds of the cultivars were sown among three sheets of germitest paper, in the form of rolls and moistened with $\mathrm{NaCl}$ formulated solutions, equivalent to 2.5 times the weight of the dry paper, in order to provide the osmotic potentials previously described. The rolls were placed in a germinator at $25{ }^{\circ} \mathrm{C}$. The evaluations were carried out on the fifth (first germination count) and on the eighth day after sowing, the results being expressed in percentage of normal seedlings (Brasil, 2009).

The germination speed index was conducted together with the germination test, calculated by the formula of Maguire (1962): GSI $=\left(\mathrm{G}_{1} / \mathrm{N}_{1}\right)+\left(\mathrm{G}_{2} / \mathrm{N}_{2}\right)+\ldots+\left(\mathrm{G}_{\mathrm{n}} / \mathrm{N}_{\mathrm{n}}\right)$.

GSI = germination speed index; $\mathrm{G}=$ number of seedlings normals computed in the counts; $\mathrm{N}=$ number of days from

1 st sowing, $2 \mathrm{nd}, \ldots \mathrm{n}$-th rating. And the mean germination time was calculated based on the seeds germinated daily until the eighth day after sowing, where the result was expressed in days after sowing.

To evaluate the epicotyl length and the primary root, only the normal seedlings were considered, using a graduated ruler, the results expressed in millimeters per seedling. Then, the seedlings were sectioned separating the epicotyl from the primary root to obtain the weight of the epicotyl fresh mass and dry mass of the primary root.

After weighing, the seedlings were placed in paper bags and dried in a forced air circulation oven $\left(65^{\circ} \mathrm{C} / 72 \mathrm{~h}\right)$, to determine the weight of the epicotyl dry mass and dry mass of the primary root. Afterwards, the samples were placed to cool in a desiccator and weighed again on a precision scale. The results were expressed in g per replicate.

The data were subjected to the Lilliefors test and to the test of Bartlett $(\mathrm{p}<0.05)$ to verify normality and homogeneity, respectively. The data were subjected to analysis of variance at a 5\% probability level of error and subsequent regression analysis. When significant, the effects of the cultivars were studied by the F test $(\mathrm{p}<0.05)$, while the effects of osmotic potentials were studied by means of regression analysis, choosing the appropriate models to represent them according to their biological behavior, the significance of the model coefficients and the value of the coefficient of determination $\left(\mathrm{R}^{2}\right)$, performed using the SISVAR statistical software (Ferreira, 2011).

\section{Results and Discussion}

For all variables in the experiment, a significant interaction was found between the evaluated factors, and for most variables, an adequate experimental precision was observed, with coefficient of variation, less than $10 \%$ or between 10 and $20 \%$, according to the criteria established by Pimentel-Gomes (1985). The results of this statistical parameter grant reliability to the inferences to be made about the average performance of the cultivars in relation to considered salinity levels.

In relation to germination, it was observed that, the lack of salinity (control treatment) resulted in an estimated average germination of $100 \%$ in the seeds of the chickpea cultivars BRS Cícero and BRS Aleppo (Figure 1A). However, these values were not maintained when $\mathrm{NaCl}$ was added to the substrate, negatively affecting seed germination as $\mathrm{NaCl}$ concentration increased, that is, as the osmotic potential became more negative. The osmotic potential $-0.6 \mathrm{MPa}$ caused a reduction in germination of $71 \%$ for 'BRS Cícero' and $76 \%$ for 'BRS Aleppo', when compared to the initial physiological quality of the seeds. It was also observed that at the potentials -0.4 and $-0.6 \mathrm{MPa}$, the germination of cultivars was similar. 
Figure 1. Germination (A), germination speed index (B) and mean germination time (C) of chickpea cultivars exposed to different osmotic potentials.

+ Cicero $\mathrm{Y}=113.800000-144.000000 \mathrm{x} \quad \mathrm{R}^{2}: 78.58 \%$

-.... Aleppo Y- $109.800000 \cdot 130.000000 x R^{2}=85,73 \%$.

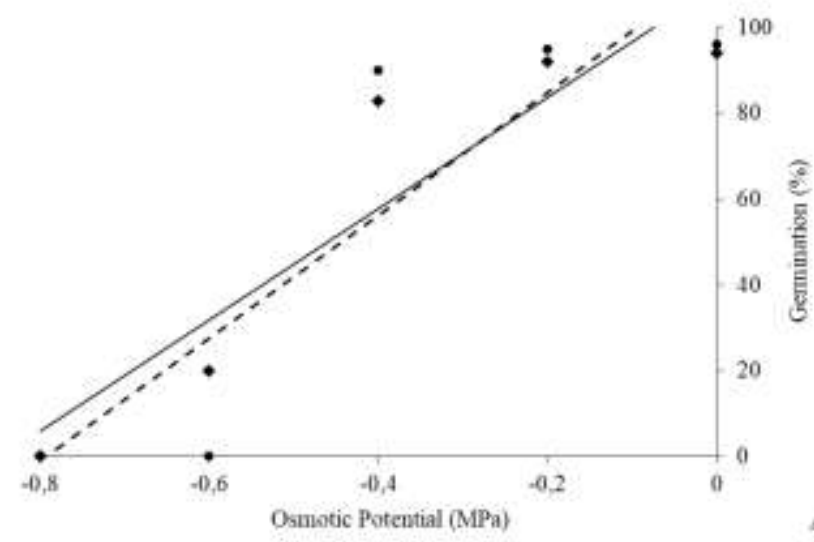

- Cicero $\dot{\mathrm{Y}}-36.633334-41.675001 \mathrm{Lx} \mathrm{R}^{2}: 88.60 \%$

- - . Aleppo $Y=36.052499-48.112499 x \cdot R^{2}: 91.44 \%$

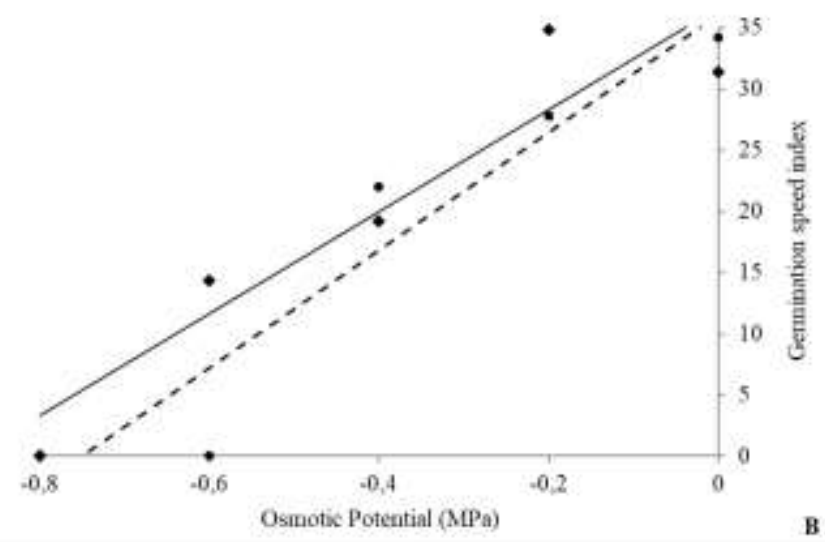

- C Ciceto $Y-1.334287+8.51679 x-11.955750 \mathrm{X}^{2} \quad \mathrm{~B}^{2}: 60.00 \%$

-... Aleppo $\mathrm{Y}=1.715852+2.26489 \mathrm{x}-6.045246 \mathrm{x}^{2} \quad \mathrm{R}^{2}=71.79 \%$

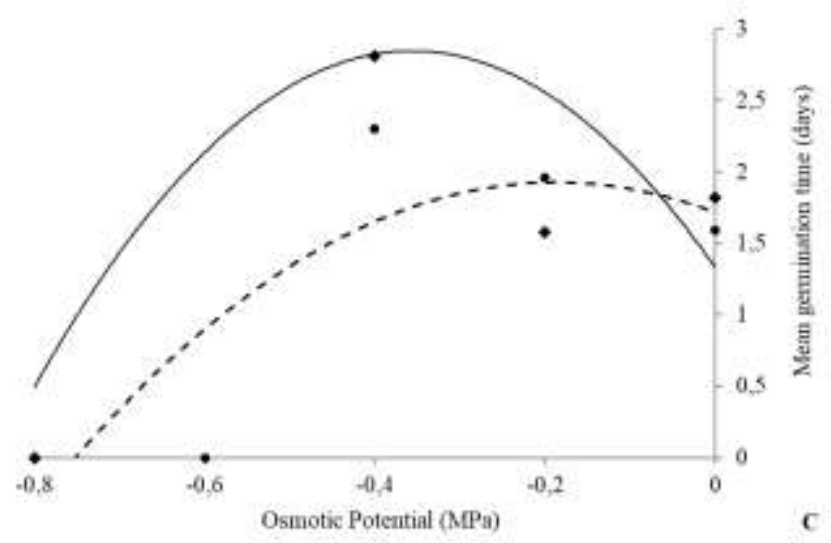

Source: Authors.

The reduction in seed germination provided by the decrease in osmotic potential induced by $\mathrm{NaCl}$ may be the result of the osmotic and or ionic effect that hinders the absorption of water by the seeds or facilitates the penetration of ions into the cells (Silva et al., 2019). As a result, a high concentration of salts in cells can also deactivate enzymes and inhibit protein synthesis (Nasr et al., 2011; Taiz \& Zeiger, 2013).

The reduction in germination due to the increase in water deficit caused by salt stress at $-0.4 \mathrm{MPa}$ was also observed in melon seeds by Pinheiro et al. (2017). On the other hand, seeds of chia (Salvia hispânica L.) and sesame (Sesamum indicum L.) do not tolerate osmotic potentials of less than -0.15 and -0.2 MPa, respectively (Medeiros et al., 2015; Stefanello et al., 2017).

When assessing seed vigor using the germination speed index (GSI), it was found reduction was observed in the percentage of normal seedlings from the potential of $-0.2 \mathrm{MPa}$, for both cultivars in the study. It is observed that the reduction in the osmotic potential of the substrate solution for both cultivars slowed the germination of the chickpea seeds, and irregularly distributed over time (Figure 1B).

It is possible that the conditions of saline stress caused a reduction in the osmotic potential of the medium and, consequently, an increase in the water soaking time by the seeds (Marques et al., 2011). Thus, the mobilization of enzymes 
responsible for germination occurred and, probably, a delay in the synthesis of the $\alpha$-amylase enzyme, thus causing the prolongation of the germination process. The seeds from the cultivar BRS Cícero showed to be more tolerant in relation to cultivar BRS Aleppo at the osmotic potential -0.6 MPa. In the more saline potential (-0.8 MPa), "BRS Aleppo" showed a null GSI value (Figure 1B).

The results of the mean germination time (MGT) of the chickpea cultivar seeds in the absence of salinity, the seeds of the cultivars BRS Cícero and BRS Aleppo obtained an estimated MGT of 1.3 and 1.7 days, respectively (Figure 1C). For 'BRS Aleppo' the maximum seed MGT (1.92 days) estimated by the regression equation occurred at the osmotic potential of -0.2 MPa. While, for the cultivar BRS Cícero, the maximum MGT of 2.82 days was reached at the osmotic potential - $0.4 \mathrm{MPa}$. It was possible to verify in the subsequent potentials a reduction in the mean germination time of the seeds of the cultivars as they did not start the germination process. It was also noted that, in the osmotic potentials -0.4 and $-0.6 \mathrm{MPa}$, the mean germination time of the seeds of the cultivar BRS Cícero was higher in relation to 'BRS Aleppo'.

The delay in the germination observed by the highest MGT results from the changes in the water intake by the seeds, caused by salinity. This is the first step to the germination process, the imbibition phase. According to Marcos-Filho (2015), it is necessary that the seeds reach an adequate level of hydration during in this phase, so that the metabolic processes of seeds and growth of the embryonic axis are reactivated.

Regarding the length of the epicotyl and primary root, in the control treatment seedlings, the values observed between the two cultivars were higher, however, the application of $\mathrm{NaCl}$ and the increase in salt stress resulted in a constant reduction in the length of the epicotyl and the root of the seedlings (Figure 2A and 2B). In relation to the PRL, the seedlings of the control treatment did not show significant difference between cultivars, however, at the osmotic potentials -0.2 and $-0.4 \mathrm{MPa}$ the cultivar BRS Aleppo had the longest root length (Figure 2B). 
Figure 2. Epicotyl length (A), length of primary root (B), epicotyl fresh weight (C), fresh weight of primary root (D), epicotyl dry weight $(\mathrm{E})$ and dry weight of primary root $(\mathrm{F})$ of chickpea cultivars exposed to different osmotic potentials.

- C Cicero $\mathrm{Y}=21.075000-28.300000 \times \mathrm{R}^{2}: 96.90 \%$

-...-Aleppo $\hat{Y}=20.610000-41.100000 \times R^{2}: 80.62 \%$

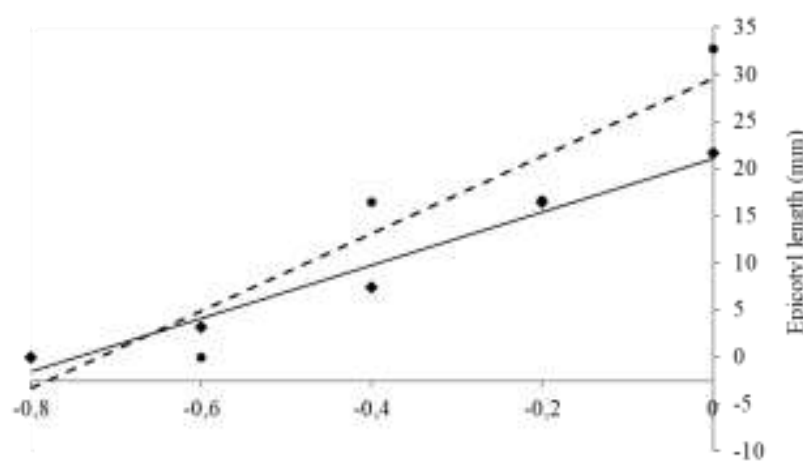

Osmotic potential (MPa)

- Ciceno $Y-61309450-56,106124 \times R^{2}: 38.00 \%$

-...-Alespo $Y=50.902050-63.466250 \mathrm{R} R^{2}: 73.82 \%$

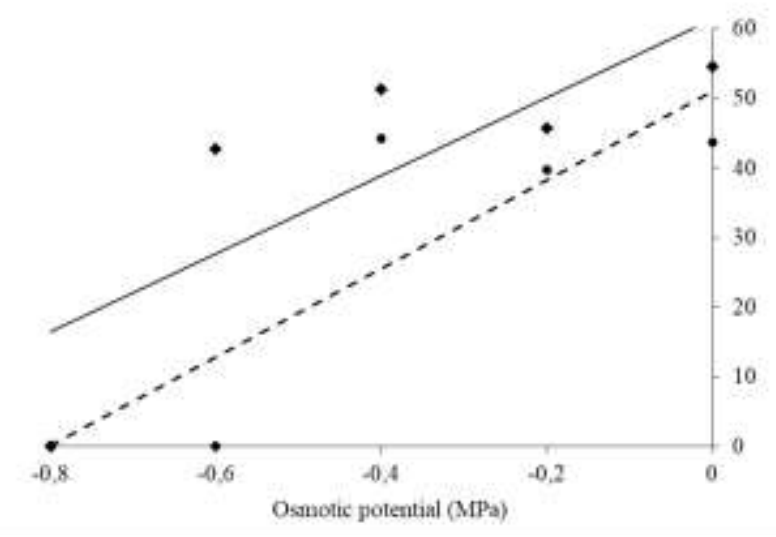

- —CKero $\hat{Y}=18.721450-20.6532508 R^{1}: 91.7796$

-.....Neqpo $Y=11.809850-16,435879 x R^{2}-88.740$

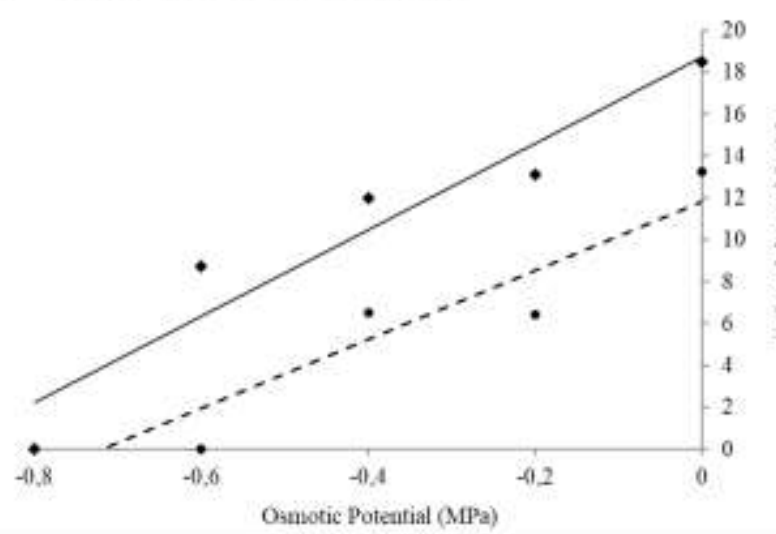

+. Cisero $\mathrm{Y}=78280000-121$ w00000 Rt : 67949

- … Aleppo $8-60.84571-16925714 x+116.6965 x^{3} R^{2}: 98.11 \%$

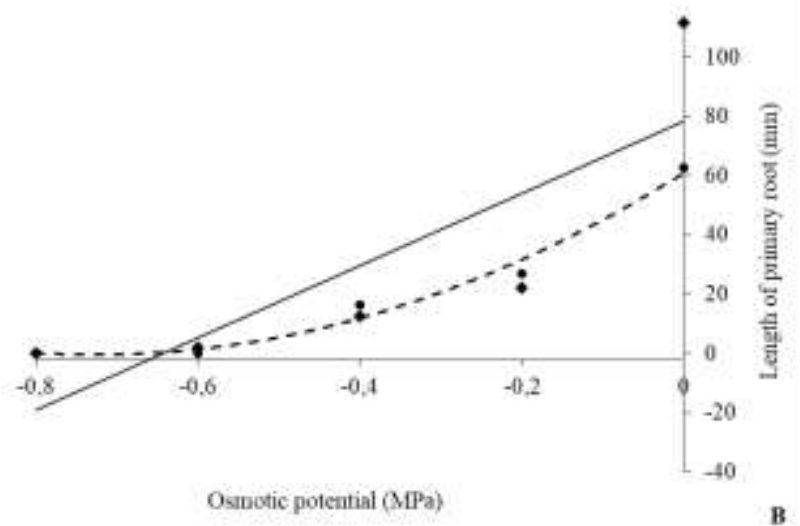

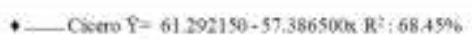

•.... Aleppo for 47.801150-59.580125x $\mathrm{K}^{2}=73.68 \%$

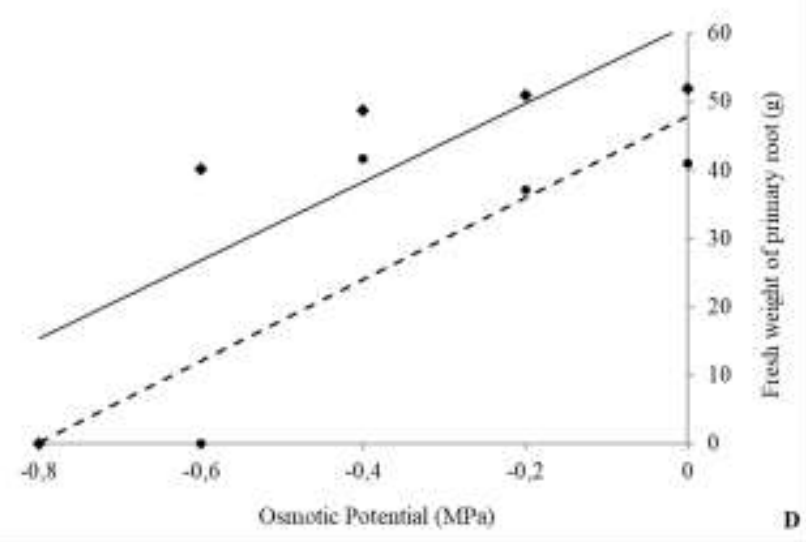

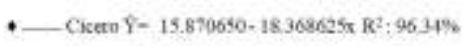

-...-Aleppo $Y-8.522300-12.915375 \times R^{2}=84,7074$

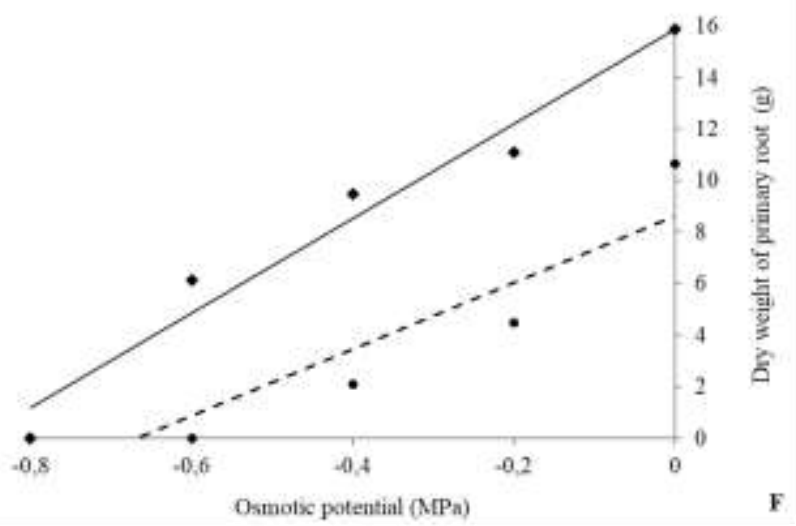

Source: Authors.

A severe salt stress may completely inhibit cell division and expansion, causing the death of the plant. Under stress conditions, the stomata close, which limits the absorption of carbon dioxide (Osakabe et al., 2014). In general, plants in conditions of water restriction tend to grow less, and the inadequate photosynthesis is one of the main causes of the reduction of growth (Silva et al., 2019). 
For the fresh and dry mass of the epicotyl and the primary root (Figure 2C, 2D, 2E and 2F), it was found that the cultivars showed a similar behavior during salt stress. These variables decreased as the osmotic potential was reduced with the highest recorded values of seedlings formed from the seeds of the control treatment ( $0 \mathrm{MPa})$ and the lowest from the seeds submitted to the osmotic potential -0.8 MPa. Thus, high salt concentrations significantly compromise the accumulation of fresh and dry mass in chickpea. The comparison between the cultivars showed similar results for these variables, where 'BRS Cícero' seeds stood out for being more vigorous and tolerant to salinity than those of 'BRS Aleppo' (Figure 2).

The reduction in the accumulation of fresh and dry mass of the epicotyl and root due to the increase in salt stress indicates the inefficiency of the photosynthetic process, so that the products derived from photosynthesis are not sufficient to supply the needs of the organs of the plants while promoting their growth (Oliveira et al., 2015). Seedling development processes are sensitive to salt stress, which means that the growth and biomass production variables are good criteria for assessing the degree of stress and the tolerance of plants to salinity.

The results reveal the importance of evaluating the osmotic potentials of the substrate, which are considered critical for the germination of seeds and growth of chickpea seedlings. In addition, they allow a careful selection of cultivars that can tolerate salt stress conditions in the medium. Therefore, such conditions of salt stress cause the seeds to require a greater number of days to germinate, which is not desirable in field conditions, as the delay in germination predisposes the seeds to a greater exposure to the action of pathogens, attack of insect pest and loss of vigor. Thus, the relationship between the osmotic potential of the environment and germination time is an important, especially in regions where soils are affected by salts, serving as a basis for farmers in the proper management of their crops.

\section{Conclusion}

Osmotic potentials of less than -0.4 MPa are detrimental to the physiological quality of seeds and growth of chickpea seedlings.

The chickpea seeds of the cultivar BRS Cícero are more tolerant to salinity than the seeds of 'BRS Aleppo', and the cultivar BRS Aleppo has a longer epicotyl length in comparison to 'BRS Cícero' when subjected to the same conditions of salt stress.

\section{Acknowledgments}

To the Coordenação de Aperfeiçoamento de Pessoal de Nível Superior - Brasil (CAPES) - Finance Code 001, to the National Council for Scientific and Technological Development (CNPq) and to the Research Support Foundation of the State of Minas Gerais (FAPEMIG), for granting scholarships of study; to Embrapa Hortaliças, for the supply of chickpea seeds; to Epamig and Unimontes, for the technical support for the development of this experimente.

\section{References}

Acosta-Motos, J. R., Ortuno, M. F., Berna-Vicente, A., Dias-Vivancos, P., Sanchez-Blanco, M. J. \& Hernandez, J. A. (2017). Plant responses to salt stress: adaptive mechanism. Agronomy, 7(1), 18-58.

Alqahtani, M., Roy, S. J. \& Tester, M. (2018). Increasing salinity tolerance of crops. In: Meyers, R. A. Encyclopedia of sustainability science and technology. Ed. New York, Springer.

Avelar, R. S., Costa, C. A., Rocha, F. S., Oliveira, N. L. C. \& Nascimento, W. M. (2018). Yield of chickpeas sown at different times. Revista Caatinga, 31(4), 900-906.

Brasil. Ministério da Agricultura e Reforma Agrária. (2009). Regras para Análise de Sementes. SAND/DNDV/CLAV.

Chauhan, Y., Allard, S., Williams, R., Williams, B., Mundreec, S., Chenud, K. \& Rachaputi, N. C. (2017). Characterisation of chickpea cropping systems in Australia for major abiotic production constraints. Field Crops Research, 204, 120-134. 
Deepa, N. \& Arumugam, T. (2019). Salinity tolerance in vegetable crops: A review. Journal of Pharmacognosy and Phytochemistry, 8(3), $2717-2721$.

Dias, N. S., Blanco, F. F., Souza, E. R., Ferreira, J. F., Souza-Neto, O. N. \& Queiroz, I. S. R. (2016). Efeitos dos sais na planta e tolerância das culturas à salinidade. In: Gheyvi, H. R., Dias, N. S., Lacerda, C. F. \& Gomes-Filho, E. Manejo da salinidade na agricultura: Estudo básico e aplicados. Ed. Fortaleza: Instituto Nacional de Ciência e Tecnologia em Salinidade.

Ferreira, A. C. T., Felito, R. A., Rocha, A. M., Carvalho, M. A.C. \& Yamashita, O. M. (2017). Water and salt stresses on germination of cowpea (Vigna unguiculata cv. BRS Tumucumaque) seeds. Revista Caatinga, 30(4), 1009-1016.

Ferreira, D. F. (2011). Sisvar: a computer statistical analysis system. Ciência e Agrotecnologia, 35(6), 1039-1042.

Iqbal, S., Khan, A. M., Kashmala, I. D., Moatter, K., Ahmed, T., Gilani, S. A., Kumar, M., Yusuf, M. A., Nigam, M. \& Kumar, M. (2018). An update on genetic modification of chickpea for increased yield and stress tolerance. Molecular Biotechnology, 60, 651-663.

Kumar, M., Yusuf, M. A., Nigam, M. \& Kumar, M., 2018. An update on genetic modification of chickpea for increased yield and stress tolerance. Molecular Biotechnology, 60(8), 651-663.

Laghmouchi, Y., Belmehd, O., Bouyahya, A., Senhaji, N. S. \& Abrini, J. (2017). Effect of temperature, salt stress and pH on seed germination of medicinal plant Origanum compactum. Biocatalysis and Agricultural Biotechnology, 10, 156-160.

Machado, R. M. A. \& Serralheiro, R. P. (2017). Soil salinity: effect on vegetable crop growth. management practices to prevent and mitigate soil salinization. Horticulturae, 3(2), 30- 43.

Maguire, J. D. (1962). Speed of germination aid in selection and evaluation for seedling emergence and vigour. Crop Science, 2, $176-177$.

Marcos-Filho, J. (2015). Fisiologia de sementes de plantas cultivadas. (2nd ed.), ABRATES.

Marques, E. C., Freitas, V. S., Bezerra, M. A., Prisco, J. T. \& Gomes-Filho, E. (2011). Efeitos do estresse salino na germinação, emergência e estabelecimento da plântula de cajueiro anão precoce. Revista Ciência Agronômica, 42(4), 993-999.

Medeiros, D. S., Alves, E. U., Sena, D. V. A., Silva, E. O. \& Araújo, L. R. (2015). Desempenho fisiológico de sementes de gergelim submetidas a estresse hídrico em diferentes temperaturas. Semina: Ciências Agrárias, 36(5), 3069-3076.

Merga, B. \& Haji, J. (2019). Economic importance of chickpea: Production, value, and world trade. Cogent Food \& Agriculture, 5, 1-12.

Nasr, S. M. H., Parsakhoo, A., Naghavi, H. \& Koohi, S. K. S. (2011). Effect of salt stress on germination and seedling growth of Prosopis juliflora (Sw.). New Forests, 43, 45-55.

Nascimento, M. D. G. R., Alves, E. U., Silva, M. L. M. \& Rodrigues, C. M. (2017). Lima bean (Phaseolus lunatus L.) seeds exposed to different salt concentrations and temperatures. Revista Caatinga, 30(3), 738-747.

Oliveira, F. A., Sá, F. V. S., Paiva, E. P., Araújo, E. B. G., Souto, L. S., Andrade, R. A. \& Silva, M. K. N. (2015). Emergência e crescimento inicial de plântulas de beterraba cv. Chata do Egito sob estresse salino. Agropecuária Científica no Semiárido, 11(1), 01-06.

Pereira, I. C., Catão, H. C. R. M. \& Caixeta, F. (2020). Seed physiological quality and seedling growth of pea under water and salt stress. Revista Brasileira de Engenharia Agrícola e Ambiental, 24(2), 95-100.

Pimentel-Gomes, F. (1985). Curso de estatística experimental. (11th ed.), Esalq.

Pinheiro, D. T., Dias, D. C. F. S. \& Araújo, J. O. (2017). Germination of melon seeds under water and thermal stress. Journal of Seed Science, 39(2), 440-447.

Sa, F. V., Santos, M. G., Barros Junior, A., Alburquerque, J. R. T., Souza, A. R. E. \& Ribeiro, R. M. P. (2020). Tolerance of peanut (Arachis hypogea) genotypes to salt stress in the initial phase. Revista Brasileira de Engenharia Agrícola e Ambiental, 24(1), 37 - 43.

Salisbury, F. B. \& Ross, C. W. (1992). Plant physiology. Wadsworth Publishing Company, Belmont, USA.

Stefanello, R., Viana, B. B. \& Neves, L. A. S. (2017). Resposta fisiológica de sementes de chia e linhaça ao estresse hídrico. Iheringia, 72(2), $161-163$.

Silva, M. F., Araújo, E. F., Silva, L. J., Amaro, H. T. R., Dias, L. A. S. \& Dias, D. C. F. (2019). Tolerance of crambe (Crambe abyssinica Hochst) to salinity and water stress during seed germination and initial seedling growth. Ciência e Agrotecnologia, 43, 1-13.

Osakabe, Y., Osakabe, K., Shinozaki, K. \& Tran, L. S. P. (2014). Response of plants to water stress. Frontier in Plant Science, 5(86), 1-8.

Taiz L, \& Zeiger E, 2013. Fisiologia Vegetal. ARTMED. 